DOI: 10.46340/eujem.2020.6.3.6

\author{
Nataliya Andryeyeva, ScD in Economics \\ ORCID iD : http://orcid.org/0000-0002-9960-559X \\ Institute of Market Problems and Economic and Ecological Research \\ of NAS of Ukraine \\ Hanna Tiutiunnyk, PhD in Economics \\ ORCID iD : http://orcid.org/0000-0003-4864-6129 \\ Institute of Market Problems and Economic and Ecological Research \\ of NAS of Ukraine
}

\title{
SMART SPECIALIZATION AS A MODERN APPROACH OF CREATION THE INVESTMENT AND INNOVATION POLICY OF THE REGIONS`ENVIRONMENTAL MANAGEMENT ${ }^{1}$
}

\begin{abstract}
The article defines the relationship of essence the innovative approach to regional spatial development with the specifics of shaping the investment and innovation policy of regions' environmental management. It is substantiated that in the conditions of aggravation and deepening of ecological problems, degradation of environment and natural resources in Ukraine, one of the instruments contributing to the implementation of European standards in the economy of regional nature management is eco-innovation. The practical solution to this problem should be based on defining a modern approach to the regional innovation and investment policy of nature management, taking into account the existing natural resource potential of the region. It is determined that the implementation of SMART-specialization best practices is an appropriate approach.
\end{abstract}

Keywords: smart specialization, regional policy, investment, innovation, environmental economics.

Introduction. Exacerbation and aggravation of environmental problems, degradation of the environment and natural resources have continued in Ukraine over the past decades. The reason for this is that Ukraine does not sufficiently consistently implement a single state (national) environmental policy, does not introduce the principles of nature rational use and minimize the negative impact on environmental objects when conducting anthropogenic activities at the regional level.

An important component of national environmental policy is the state's regional environmental policy. The main tendencies of regional policy development testify to the lack of attention of the need to ensure the regional policy greening in the conditions of "green" growth and qualitative restoration of the regions potential on ecological, socio-economic bases, harmonization of geo-spatial relations between the country and regions, which requires significant changes in the context of regional policy reform and in the system of formation and implementation of state environmental policy. Environmental innovation is recognized as one of the instruments contributing to the implementation of European standards in the regional economy, as an indicator of sustainable and balanced development in a competitive environment. This is confirmed by international programmatic documents and statistical reports that treat eco-innovations as innovations that increase the efficiency of natural resource use from an economic point of view, reduce the negative impact of human activity on the environment or increase the sustainability of the ecological system to the load. The introduction of eco-innovation contributes to the development and expansion of the market for eco-friendly

\footnotetext{
${ }^{1}$ Дослідження виконано в межах НДР " Домінанти інвестиційно-інноваційної політики природокористування національної економіки" бюджетної програми "Підтримка розвитку пріоритетних напрямів наукових досліджень" (КПКВК 6541230) / Research performed within the RDW" Dominants of the investment-innovation policy of the nature management of national economy "budget program" Support for the development of priority areas for scientific research" (CTCC 6541230)
} 
goods and services ${ }^{1}$. The practical implementation of this policy should be based on defining a modern approach to the regional innovation and investment policy of nature management, which take into account the existing natural resource potential of the region. To this approach, the authors consider it appropriate to refer the implementation of EU best practices in SMART - specialization.

Aim. The purpose of the research work is to determine the relationship of essence the innovative approach to regional spatial development with the specificity of the formation of investment and innovation policy of regions environmental management.

Under the investment and innovation policy of environmental management of the region, the authors understand the activities of state and regional bodies aimed at creating favorable regulatory and economic conditions for environmental investments in general and investments in environmental innovations, stimulating the process of formation of investment conditions of environmental management, as well as the formation of environmental markets environmental investments.

Materials and methods. Among the scientific papers dealing with the methodology and method of regional smart specialization are the works of Ortega A.R., McCann, P., Perianez-Forte, I., Cervantes, M., Larosse, J., Sanchez, L. ${ }^{2}$, Sugimoto, C.R., Robinson-Garcia, N. Costas, R. ${ }^{3}$, Delaney, K. and Osborne, L. ${ }^{4}$ and others, which discuss the basic conceptual provisions and provide recommendations for their implementation. The smart specialization concept that underpins the European Commission's regional development policy was first developed by the European Commission's Knowledge for Growth Expert Group on Knowledge for Growth in the process of forming a single European Research Area (ERA). The regulations governing the procedures and procedures for regional smart specialization in the EU are presented on the S3 platform, established by the European Commission in 2011. Smart specialization combines industrial, innovation and education policies aimed at selecting a limited number of priority areas for investment within the region, focusing on its strengths and comparative advantages.

Results and discussion. The concept developers were tasked with extending public investment in knowledge and innovation. Support for business research in areas such as biotechnology, nanotechnology by state and especially regional authorities had to complement other productive areas in order to discover domestic potential and gain benefits already on the international market. The initial idea was quite simple: the concentration of public resources in investment, in knowledge, in relation to specific enterprises in order to strengthen the comparative advantage in existing or new areas. However, the conceptual and political implications of "smart specialization" are much more complex and extend to three distinct areas: the primary role of scientific, technological and economic specialization in the development of comparative advantage and economic growth; policies aimed at identifying priority areas of activity and management decisions that shift the leading role to the regions, to private shareholders and entrepreneurs, in the process of transforming specialization policies into real socio-economic outcomes. Thus, "smart specialization" is a concept of economic growth driven by innovation, and many of its main elements have repeatedly been mentioned in the context of regional development, innovation, industrial policy.

The basic principles of smart specialization that should underpin the regional strategy are the following:

1) smart specialization is a local approach, which means that it builds on the assets and resources available to regions and Member States and their specific socio-economic challenges to identify unique opportunities for development and growth;

2) formulate your own strategy means choosing investment priorities: Member States and regions should only support a limited number of clearly defined investment priorities based on knowledge and / or clusters; specialization means focusing on competitive forces and realistic growth potentials supported by a critical mass of activity and entrepreneurial resources;

\footnotetext{
${ }^{1}$ Martiienko, A. I., Bondarenko, S. A. (2015). Ekolohichni innovatsii v rehional'niy innovatsiyniy systemi [Ecological innovations in the regional innovation system]. Efektyvna ekonomika [An efficient economy], 8.

$<$ http://www.economy.nayka.com.ua/?op=1\&z=4232> (2020, April, 06).

${ }^{2}$ Ortega, A. R., McCann, P., Perianez-Forte, I. and others (2013). Innovation-driven growth in regions: the role of smart specialisation. OECD Science, Technology and Industry Policy Papers, 12. Paris: OECD/ODCE.

${ }^{3}$ Sugimoto, C. R., Robinson-Garcia, N., Costas, R. (2016). Towards a Global Scientific Brain: Indicators of

Researcher Mobility using co-affiliation Data. Paper presented at the OECD Blue Sky Conference. Ghent, Belgium.

${ }^{4}$ Delaney, K., Osborne, L. (2013). Public sector horizon scanning-stocktake of the Australasian joint agencies scanning network. Journal of Futures Studies, 17 (4), 55-70.
} 
3) priority setting should not be top-down - It should be an inclusive and interactive stakeholder process where market forces and the private sector identify and produce information on new developments, and the government evaluates the results and empowers the actors to realize this potential;

4) the strategy should cover a broad view of innovation, support for technological as well as practical and social innovation, enabling each region and the Member States to make policy choices according to their unique socio-economic context;

5) a quality strategy should include a robust monitoring and evaluation system as well as a review mechanism for updating strategic choices ${ }^{1}$.

The European Commission has now identified four major challenges to addressing smart specialization strategies, promoting new growth patterns at the regional level and directing investment in innovative sectors with significant growth potential and high added value. These challenges are attributed ${ }^{2}$ :

- further reform of research and innovation systems in the regions;

- enhanced cooperation in innovative investments between regions;

- the use of research and innovation in less developed and industrial transitional regions;

- use of synergies and complementarity between EU policies and instruments.

Ukraine started the process of implementing the smart specialization approach in 2016, headed by its Ministry of Economy, Trade and Agriculture of Ukraine. The main partners of smart specialization implementation in Ukraine are the Directorate General of the European Commission and its Joint Research Center, which owns the smart specialization methodology in the EU and beyond. In 2018, a Cabinet resolution came into force requiring all regions to define at least one strategic goal based on smart specialization within the framework of a regional development strategy. Thereafter, relevant trainings were held for representatives of all regions. The first stage of smart specialization implementation, i.e. analysis of economic, innovative and scientific potential of the regions, has partially completed. The next is a process of further research based on an analysis with representatives of business, the public, science and local authorities, which can be priorities for innovative development of the region, based on its strengths and available resources.

A key difference between so-called "smart specialization" from traditional industrial policy, even innovative, is the interactive process, labeled by the concept authors as "entrepreneurial search", in which the market and the private sector are exploring new business opportunities while the government supports actors, the largest to the extent capable of realizing new potential.

The authors believe that the implementation of the innovative approach of regional smart specialization should be oriented to the investment-innovation policy of nature management and be based on the definition of investment-innovative and natural-resource potentials. The natural resource potential of the state (region) is a collection of identified and suitable for use natural resources of the state (region) at a given level of production. It is an essential part of the national wealth of the country (region) and provides them with raw material and fuel independence and security.

The criteria for assessing the natural resource potential are: the cost of primary production, which can be obtained with its full and rational use over a certain period (for example, per year) and its share of GDP; the share of raw materials and fuel in the country (region) in their world stock (or in the stock of the country as a whole); number of years of possible extraction of resources in the volume and assortment required for the country (region); the specific value of resources per 1 person or per $\mathrm{km} 2$ of territory.

It should be noted that, according to domestic analysts, the weaknesses of Ukraine in terms of innovative activity in international indexes are recognized as: "environmental sustainability", institutions, protection of intellectual property rights, state of development of clusters, development of broadband Internet, innovative environment. In Ukraine, systemic obstacles that impede the formation of "reasonable specialization" are related to the centralized and universal nature of strategic planning for economic development, which does not take into account the conditions and needs of specific regions (Tables 1,2).

\footnotetext{
${ }^{1}$ European Commission website (2020). Knowledge for Growth: European Issues and Policy Challenges $<$ http://ec.europa.eu/invest-inresearch/pdf/download_en/knowledge_for_growth_bat.pdf $>$ (2020, April, 06).

${ }^{2}$ Access to European Union law (2020). Communication from the commission to the european parliament, the council, the european economic and social committee and the committee of the regions. A Budget for Europe $2020-$ Part II: Policy fiches. COM (2011) 500 final $<$ https://eur-lex.europa.eu/resource.html?uri=cellar:d0e5c248-4e 35-450f8e303472afbc7a7e.0011.02/DOC_4\&format=PDF> (2020, April, 06).
} 
Dynamics of the rating of some countries according to the Innovation Efficiency Index for $2010-2018$

\begin{tabular}{|l|c|c|c|c|c|c|c|}
\hline \multicolumn{1}{|c|}{ Country } & 2010 & 2012 & 2014 & 2015 & 2016 & 2017 & 2018 \\
\hline Ukraine & 54 & 14 & 14 & 15 & 12 & 11 & 5 \\
\hline Kazakhstan & 77 & 131 & 118 & 124 & 108 & 116 & 111 \\
\hline China & 14 & 1 & 2 & 6 & 7 & 3 & 3 \\
\hline USA & 63 & 70 & 57 & 33 & 25 & 21 & 22 \\
\hline Germany & 56 & 11 & 19 & 13 & 9 & 7 & 9 \\
\hline Poland & 85 & 80 & 76 & 93 & 66 & 48 & 42 \\
\hline India & 101 & 2 & 31 & 31 & 63 & 53 & 49 \\
\hline Japan & 18 & 88 & 88 & 78 & 65 & 49 & 44 \\
\hline Switzerland & 15 & 5 & 6 & 2 & 5 & 2 & 1 \\
\hline Luxembourg & 5 & 8 & 9 & 3 & 1 & 1 & 2 \\
\hline
\end{tabular}

Source: generated based on ${ }^{l}$

Existing mechanisms aimed at economic development do not have mechanisms that take into account the specific features of regions: geographical, resource, environmental, existing production and infrastructure.

Table 2

Ukraine's Ranking by Bloomberg Innovation Index 2018-2019

\begin{tabular}{|c|c|c|c|c|c|c|c|c|}
\hline & 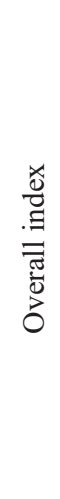 & 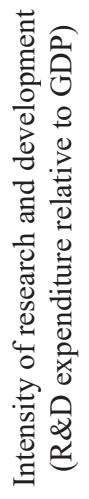 & 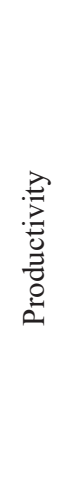 & 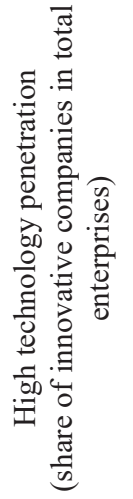 & 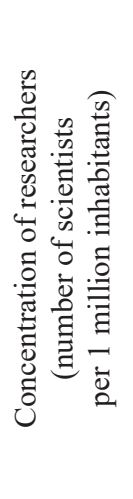 & 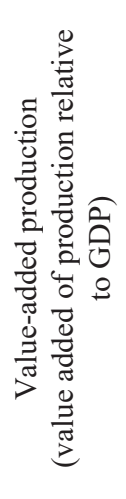 & 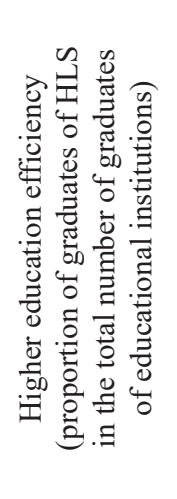 & 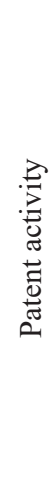 \\
\hline Ukraine 2018 & 46 & 47 & 50 & 32 & 46 & 48 & 21 & 27 \\
\hline Ukraine 2019 & 53 & 54 & 60 & 37 & 46 & 58 & 28 & 35 \\
\hline
\end{tabular}

Source: generated based on ${ }^{2}$

\footnotetext{
${ }^{1}$ Global Innovation Index (2020). The Global Innovation Index 2010-2018. <http://www.globalinnovationindex.org> (2020, April, 06).

${ }^{2}$ Pysarenko, T.V., Kvasha, T.K. and others (2019). Stan innovatsiynoyi diyal'nosti ta diyal'nosti u sferi transferu tekhnolohiy v Ukraini u 2018 rotsi: analitychna dovidka [State of innovation and technology transfer activities in Ukraine in 2018: analytical report]. Kyiv: UkrINTEI.
} 
The room for maneuver available to regional authorities within national strategies remains too small to really take into account all of these factors.

Within the framework of regional economic strategies, there are two significant problems: first, they are focused, first of all, on the creation of new industries, not taking into account the development and restoration of existing ones, which would allow efficient use of natural resources of a particular region. Secondly, in many cases, when drafting socio-economic development strategies, their authors seek to cover the largest number of spheres, neglecting the natural-resource and nature-specific nature of the region, an understanding of which is one of the key aspects of "smart specialization".

In Ukrainian practice, there are no specialized mechanisms and methodological support for analyzing the economic conditions in the region, which would allow to identify and focus on the most promising areas of activity. Finally, there is no mechanism for establishing links between the Ukrainian entities to form production in such a way that involvement of industries in other regions could be attracted for the purpose of technological processes optimization, logistic and other costs reduction. The Ukrainian system of economic development differs in fragmentation and isolation of regions from each other, where interregional production chains are not always formed. However, these problems, although systemic, can be solved in the presence of a comprehensive approach, which comes primarily from the regions and the entrepreneurs themselves within the framework of an "entrepreneurial search" for a balanced investment and innovation policy for the use of the regions.

Conclusions. Regional smart-specialization is a model of structural change that leads to diversification of the region's economy based on the development of new directions of production activity. Its result is much broader than the simple technological modernization of basic industries. Rather, it is a structural evolution of the entire regional economy as a cumulative process that links the present and future strengths of the regional economy to a particular field of activity and knowledge.

It should be noted that the modern view of the implementation of the European approach to regional smart - specialization of Ukraine should be combined with the formation of a balanced environmentally oriented investment and innovation policy based on the assessment of the existing natural resource potential.

\section{References:}

1. Martiienko, A. I., Bondarenko, S. A. (2015). Ekolohichni innovatsii v rehional'niy innovatsiyniy systemi [Ecological innovations in the regional innovation system]. Efektyvna ekonomika [An efficient economy], 8. $<$ http://www.economy.nayka.com.ua/?op=1\&z=4232> (2020, April, 06). [in Ukrainian].

2. Ortega, A. R., McCann, P., Perianez-Forte, I. and others (2013). Innovation-driven growth in regions: the role of smart specialisation. OECD Science, Technology and Industry Policy Papers, 12. Paris: OECD/ODCE. [in English].

3. Sugimoto, C. R., Robinson-Garcia, N., Costas, R. (2016). Towards a Global Scientific Brain: Indicators of Researcher Mobility using co-affiliation Data. Paper presented at the OECD Blue Sky Conference. Ghent, Belgium. [in English].

4. Delaney, K., Osborne, L. (2013). Public sector horizon scanning-stocktake of the Australasian joint agencies scanning network. Journal of Futures Studies, 17 (4), 55-70. [in English].

5. European Commission website (2020). Knowledge for Growth: European Issues and Policy Challenges $<$ http://ec.europa.eu/invest-inresearch/pdf/download_en/knowledge_for_growth_bat.pdf> (2020, April, 06). [in English].

6. Access to European Union law (2020). Communication from the commission to the european parliament, the council, the european economic and social committee and the committee of the regions. A Budget for Europe 2020 - Part II: Policy fiches. COM (2011) 500 final $<$ https://eur-lex.europa.eu/resource.html?uri=cellar:d0e 5c2484e35-450f-8e303472afbc7a7e.0011.02/DOC_4\&format=PDF> (2020, April, 06). [in English].

7. Global Innovation Index (2020). The Global Innovation Index 2010-2018. $<$ http://www.globalinnovationindex.org $>$ (2020, April, 06). [in English].

8. Pysarenko, T.V., Kvasha, T.K. and others (2019). Stan innovatsiynoyi diyal'nosti ta diyal'nosti u sferi transferu tekhnolohiy v Ukraini u 2018 rotsi: analitychna dovidka [State of innovation and technology transfer activities in Ukraine in 2018: analytical report]. Kyiv: UkrINTEI. [in Ukrainian]. 